\title{
Analysis of Cost Overrun and Schedule Delays of Infrastructure Projects in Low Income Economies: Case Studies in Ethiopia
}

\author{
Solomon Melaku Belay (D), ${ }^{1}$ Seifu Tilahun, ${ }^{1}$ Mitiku Yehualaw, ${ }^{1}$ Jose Matos, ${ }^{2}$ \\ Helder Sousa $\mathbb{D}^{2},{ }^{2}$ and Endalew Temesgen Workneh ${ }^{3}$ \\ ${ }^{1}$ Faculty of Civil and Water Resource Engineering, Bahir Dar Institute of Technology, Bahir Dar, Ethiopia \\ ${ }^{2}$ Department of Civil Engineering, University of Minho, Guimaraes, Portugal \\ ${ }^{3}$ Construction Works Regulatory Authority, Addis Ababa, Ethiopia
}

Correspondence should be addressed to Solomon Melaku Belay; solomon.melaku@bdu.edu.et

Received 18 September 2021; Revised 25 October 2021; Accepted 27 October 2021; Published 17 November 2021

Academic Editor: Heap-Yih (John) Chong

Copyright (C) 2021 Solomon Melaku Belay et al. This is an open access article distributed under the Creative Commons Attribution License, which permits unrestricted use, distribution, and reproduction in any medium, provided the original work is properly cited.

\begin{abstract}
Today, several developing countries struggle to improve the cost and time performances of major infrastructure works due to various reasons. Cost overrun and delay are one of the major challenges being faced by the construction and infrastructure sector. Hence, the aim of this study is to explore the extent of cost overrun and schedule delays in building and road infrastructure projects across the Ethiopian construction industry. Primary data were collected through a structured questionnaire survey to evaluate the potential risks leading to those challenges. Various data analysis tools were employed, to investigate the critical causes of cost overrun and delays in infrastructure projects. The findings reveal that the minimum cost overrun for building construction projects is found to be $2 \%$, whereas the maximum and average cost overruns are $248 \%$ and $35 \%$, respectively. For road infrastructure projects, the minimum, maximum, and average cost overruns are found to be $1 \%, 61 \%$, and $18 \%$, respectively. Similarly, the minimum, maximum, and average delays recorded in building construction projects are $9 \%, 802 \%$, and $143 \%$, respectively, whereas, in road infrastructure projects, the minimum delay is found to be $3 \%$, the maximum delay is $312 \%$, and an average schedule delay of $110 \%$ is recorded. In addition, the top risk factors leading to cost overrun in infrastructure projects are inflation, inaccurate cost estimates, and variations, whereas the major risks causing schedule delays are variations, economic conditions, and escalation of material prices. Further, practical implications and key recommendations were provided to curb cost overrun and delay in infrastructure projects.
\end{abstract}

\section{Introduction}

The infrastructure and construction sector in the SubSaharan Africa region faces several problems and challenges ranging from quality work to severe budget constraints $[1,2]$. These challenges could lead to several instances and disputes among parties across the project life cycle [3]. One of the most common challenges the construction industry is confronting cost overrun and schedule delays in various infrastructure projects. Consequently, these problems are often regarded as a very common phenomenon in the majority of projects across developing countries [4].

Prior studies highlighted the negative impacts of cost overrun and schedule delays in numerous developing countries, such as Tanzania [5], Pakistan [6], South Africa [7], Iran [8], and Malaysia and Ghana [9]. These studies explored the negative impacts of cost overrun and schedule delays on various stakeholders involving in construction projects including owners, contractors, and the practitioners' in general. For instance, to contractors, it amounts to profit lose due to inferior performance and defamation that could threaten the firm's chances of participating in further contracts, if at fault. To client/owner, both problems in infrastructure projects indicate increased budget over the initially agreed contract amount at the onset, resulting in bad investment return. To practitioners, cost overrun and schedule delay imply failure to deliver the required work as per the specification and could well tarnish their reputations 
and result in loss of confidence by the key business owners in general.

One of the most important features to consider to enhance the overall performance of construction projects in low income economies and particularly in the Ethiopian construction industry is by exploring the aspects of cost overrun and schedule delays using actual project data. Hence, the specific objectives of this study are threefold: (1) examine the extent of cost overrun and schedule delays in infrastructure projects; (2) investigate the risk factors leading to both challenges; and (3) provide comprehensive critical recommended actions and practical implications to curb the problems imposed by potential cost overrun and schedule delays in construction projects. The findings of this paper provide a vital science-based data to various stakeholders practicing in the Ethiopian construction sector and developing countries in general.

\section{Literature Review}

In public construction projects, evaluating performance of each activity throughout the project life cycle is vital for the successful delivery of infrastructures [10]. An infrastructure project is considered successful when it is completed in the allotted time, with agreed contract budget, and within the depicted specifications [11]. It is also important to denote that successful delivery of construction projects requires the utmost cooperation and coordination of project team across the project life cycle $[12,13]$.

In contrast, many construction projects in different regions fail to meet the success criteria due to various challenges, including low level of cost and time performances [14]. Previous studies highlighted a number of causes and risk factors leading to poor cost and time performances, including different aspects of cost overrun and schedule delays in both developing and developed nations. For instance, In Jordan, the top causes of cost overrun and delay are lack of experienced construction manager, lowest bidder selection, and funding shortage by owner [15]. In India, inadequate contractor's work and experience and also poor risk management and ignorance and poor communication and coordination with the participants of the construction project are considered as major causes of poor cost and time performance [16], whereas delay in progress payment by client, changing orders by client during construction, and poor site management are regarded as the top causes in Iran [17].

Consequently, its vital to investigate the key risk factors and causes of cost overruns and schedule delays from a country specific perspective and provide key practical recommendations and check lists to curb the underlying root causes and ensure success in public infrastructure projects.

2.1. Cost Overrun in Construction Projects. In the context of construction projects, cost overruns can be expressed as the excess of actual project completion cost over contract budget amount [18]. Cost overrun is computed by the initial estimated cost, and total completion cost incurred during commissioning of the project. The difference between estimated and completion cost is termed as the magnitude of the cost overrun. In relation to this, cost overrun can be obtained by the positive difference between the completion cost of a construction project during commissioning and the contract amount agreed by the major parties during the contract signing and commencement of projects. The difference between agreed contract sum and final project cost can be expressed as [19]

$$
\text { cost ratio }(\mathrm{CR})=\frac{\text { completion cost }}{\text { contract amount }} \text {. }
$$

The ideal CR is 1.0, so, any value above this can be considered as a cost overrun.

This calculation can be converted to a percentage for ease of comparison

$$
\text { Cost overrun }=\frac{\text { Completion Cost-Original Contract Cost }}{\text { Original Contract Cost }} .
$$

It is important to denote that delivering a construction project within the planned contract budget is one of the main success criteria in construction projects.

2.2. Risk Factors Leading to Cost Overrun. Several factors affect the extent of cost overrun and schedule delays in the construction sector. These risk factors could be classified as factors related to consultant, contractor, design parameters, and information, factors related to market conditions (external factors), and factors related to project characteristics (Table 1).

2.3. Schedule Delay in Construction Projects. Construction delays are often a result of a mismanagement and can be seen as a risk for infrastructure projects, which if identified, analyzed, and managed in a systematic process of various phases of the project life cycle, could be managed, minimized, and mitigated [15]. Delay in construction project has a negative impact to key stakeholders in terms of growth in adversarial relationships, claims, litigation, arbitration, and cash-flow challenges [33]. A construction project may be regarded as a successful endeavor until it satisfies the cost, time, and quality limitations applied to it. However, it is not uncommon to see a construction project failing to achieve its goal within the specified cost, time, and quality. In order to counter the unforeseen delays beforehand the realm of "Project management" is resorted which helps mitigate the delays $[37,38]$.

\subsection{Risks Leading to Schedule Delay in Construction Projects.} Time overrun is any delay beyond the baseline construction schedule; time delay frequently occurs in all phases of a construction project and consequently increases the project total duration. Construction delays are usually caused by either the contractual parties such as client, contractor, and consultant or external factors that are beyond the control of 
TABLE 1: Risk factors leading to cost overrun.

\begin{tabular}{|c|c|c|}
\hline Category & Risks leading to cost overrun & Ref. \\
\hline Client/owner & $\begin{array}{c}\text { Type of client (public/private) } \\
\text { Client's experience level } \\
\text { Client's initial brief (clear scope definition) } \\
\text { Effective communication between client and design team } \\
\text { Client attitude towards changes (variations) } \\
\text { Client's budget/cash-flow constraints }\end{array}$ & $\begin{array}{c}{[3,20,21]} \\
{[8,22]} \\
{[20,22]} \\
{[8,23,24]} \\
{[25]} \\
{[7,21,25]}\end{array}$ \\
\hline Consultant & $\begin{array}{c}\text { Clear and detailed drawings and specification } \\
\text { Competency and experience of the consulting firm } \\
\text { Availability of database for historical cost data } \\
\text { Accuracy and reliability of cost related information } \\
\text { Project's team experience on project type } \\
\text { Completeness of cost information/estimation } \\
\text { The estimating method used } \\
\text { Level of involvement of the project manager } \\
\text { Quality of information and requirements between experts } \\
\text { Time allowed for preparing cost estimates } \\
\text { Risk sharing between the parties }\end{array}$ & $\begin{array}{c}{[7,22,26]} \\
{[20,25]} \\
{[21]} \\
{[22,23]} \\
{[9,21]} \\
{[5,14,22]} \\
{[3]} \\
{[9,20]} \\
{[7,22,26]} \\
{[8]} \\
{[9,20,27]}\end{array}$ \\
\hline Contractor & $\begin{array}{c}\text { Clarity of project information before execution } \\
\text { Complexity of design and construction } \\
\text { Clarity and quality of drawings before tendering } \\
\text { Quality of information flow during execution } \\
\text { Availability of resources (labor, material, and equipment) } \\
\text { Accuracy of bill of quantities } \\
\text { Method of construction and construction technique } \\
\text { Type of project (residential, commercial) } \\
\text { Type of project structure (concrete, steel, masonry) } \\
\text { Project size and complexity } \\
\text { Site conditions (topography, hot area, etc.) } \\
\text { Site constrains (access, storage, electricity, etc.) } \\
\text { Changes in project schedule, phasing requirements }\end{array}$ & $\begin{array}{c}{[10,28]} \\
{[29]} \\
{[3,22,30]} \\
[9,26,31]] \\
{[32]} \\
{[8,31]} \\
{[5,7,20]} \\
{[28,33]} \\
{[26,32]} \\
{[33]} \\
{[23]} \\
{[21,22,30]} \\
{[22,31]} \\
\end{array}$ \\
\hline Contract administration & $\begin{array}{c}\text { Financial status of the owner } \\
\text { Type of currency } \\
\text { Method of payments and its approval period } \\
\text { Delivery method and contractual arrangement } \\
\text { Advanced payment arrangement } \\
\text { Method of solving disputes } \\
\text { Liquidated damage amount } \\
\text { Amount and percentage of retention } \\
\text { Type and value of insurance }\end{array}$ & $\begin{array}{c}{[5,32]} \\
{[7,9,10]} \\
{[33]} \\
{[14,33]} \\
{[8,34]} \\
{[9,28,29]} \\
{[23]} \\
{[33,34]} \\
{[3]}\end{array}$ \\
\hline Project risks & $\begin{array}{c}\text { Social aspects of the project (hot spots, near settlements) } \\
\text { Segmentation (limitation of movement between areas) } \\
\text { Political situation of the country } \\
\text { Expected natural forces (floods, storms) }\end{array}$ & $\begin{array}{c}{[21,29,32]} \\
{[20,33]} \\
{[7]} \\
{[33,35]}\end{array}$ \\
\hline Market conditions (external factors) & $\begin{array}{c}\text { Level of workmanship (productivity, performance) } \\
\text { Market conditions/economic climate } \\
\text { Level of competition (number of competitors) } \\
\text { Inflation (increase in unit cost of construction materials) } \\
\text { Material availability (including raw materials) } \\
\text { Labor availability and cost } \\
\text { Currency exchange fluctuation } \\
\text { Impact of government regulations requirement } \\
\text { Unforeseeable fluctuation in labor, materials prices } \\
\text { Machinery (cost/availability/performance) }\end{array}$ & $\begin{array}{l}{[30,35,36]} \\
{[7,14]} \\
{[33]} \\
{[20,23,26]} \\
{[9,22,33]} \\
{[7,23]} \\
{[20]} \\
{[14]} \\
{[10,26,27]} \\
{[21,28]}\end{array}$ \\
\hline
\end{tabular}


the parties or force majeure. Table 2 illustrates the critical risks leading to delay in construction projects.

\section{Methodology}

This section is comprised of the overall research design, data collection, and analysis techniques used in the current study.

3.1. Data Collection. The primary data collection is collected using a structure questionnaire survey from various professionals in the Ethiopian construction sector. Along with the survey, primary historic cost and time data of various construction projects (building and road) have also been collected and used for this study. A mix of both qualitative and quantitative methodologies was employed to collect relevant data in numerous infrastructure projects. The combination of both suitable methods is suitable for data collection to answer the specific objectives as they provide an opportunity to get access to more data that could not helpful for scientific statistical analysis (Figure 1).

For the case of determining the extent of cost overrun and schedule delays, relevant project data including project documentation, archival records, survey, interviews, expert observations, participant observations, and physical artifacts were collected for both building and road projects across the Ethiopian construction sector. This in turn made the data collection complex because of the challenges to get historical data of completed projects from various sources. Each of the sources of data collection has its strengths and weaknesses while combining all the sources of the evidence is observed to provide better results instead of a single source of evidence. Recent studies also supported the use of multiple data collection and analysis tools for similar cost and time management studies [42-44].

Moreover, the current study employed various sources of data collection and analysis tools to validate for triangulation of the research techniques and therefore, the current study carefully considered and executed all possible data sources and project information to strengthen the analysis and provide relevant recommended actions, as well as comprehensive conclusion.

3.2. Sampling Design and Determination. Sampling is the selection of a subset (a statistical sample) of expert participants from within a certain statistical variable as a precondition to analyze the required data [13]. In this study, during the nature of the topic, a purposive sampling technique was employed to collect relevant data from experts working in various positions across the Ethiopian construction industry. Consequently, a total of 106 primary project data (both building and road projects) were collected to investigate the degree and severity of cost overrun and schedule delays in a larger scale.

Similarly, a total of 52 practitioners consisting of key stakeholders, including clients, contractors, consultants, and academia, participated to examine the critical risk factors leading to both problems in the Ethiopian construction industry. Similar studies also confirm that this sample size is adequate for analysis [45-47]. From the respondents, 2 have a $\mathrm{PhD}$ degree, 39 have $\mathrm{MSc}$, and the remaining 13 have $\mathrm{BSc}$ degrees in civil engineering. Similarly, from the perspective of relevant experience in the construction industry, 6 respondents have more than 15 years of experience, whereas 5 respondents (11 to 15 years), 20 respondents (6 to 10 years), and 21 respondents have 0 to 5 years of experience in the construction industry.

3.3. Data Analysis. Data analysis is the process of analyzing, testing, and connecting a number of qualitative and/or quantitative data to address specific objectives and research questions [48]. For this study, the data collected from questionnaire survey is analyzed using popular statistical analysis tool, the Statistical Package for Social Science (SPSS), version 23. To ensure the consistency of the quantitative data and to make the interpretation of results more meaningful, several initial processes were undertaken. These processes include categorizing data, editing data, coding data, and creating data files. For this study different statistical tools are implemented, including Mean Score ranking, Chi-Square Technique, Kendall's Coefficient of Concordance, and Spearman's rank correlation.

3.4. Mean Score Ranking. Mean score $(M)$ is one of the popular statistical methods that utilizes the average (mean) of a questionnaire survey response which were filled using a 5-point Likert's scale. As shown in equation (2), $M$ is calculated by averaging all responses in an item.

$$
M=\frac{\sum f \times S}{N} \quad(0<M \leq 5),
$$

where $f$ is the frequency of responses, and $\mathrm{S}$ is the score given to each attribute by a respondent from 1 to 5 .

$w$ is weighting given to each factor by respondents ranging from 1 to 5 , where $1=$ number of respondents for very low important, 2 =number of respondents for low important, 3 =number of respondents for neutral, $4=$ number of respondents for high important, and $5=$ number of respondents for very high important. The $M$ value ranges in $0<$ Mean Score $\leq 1$.

3.5. Chi-Square Test. The Chi-Square statistic is commonly used for testing relationships between categorical variables. The null hypothesis of the Chi-Square test is that no relationship exists on the categorical variables in the population; they are independent.

The Chi-Square statistic is adopted to evaluate Tests of Independence when using a crosstabulation (also known as a bivariate table). Crosstabulation presents the distributions of two categorical variables (stakeholders) simultaneously, with the intersections of the stakeholders appearing in the cells of the table. The Test of Independence assesses whether an association exists between the two stakeholders by comparing the observed pattern of responses in the cells to the pattern that would be expected if the variables were truly 
TABLE 2: Risk factors leading to schedule delays in infrastructure projects.

\begin{tabular}{|c|c|c|}
\hline Category & Risks leading to cost overrun & Ref. \\
\hline Client/owner related & $\begin{array}{c}\text { Unrealistic contract durations imposed by owner } \\
\text { Poorly defined scope } \\
\text { Client/owner interference } \\
\text { Variations (design changes/extra work) } \\
\text { Poor communication between project team } \\
\text { Slow decision making by owner }\end{array}$ & $\begin{array}{c}{[7,39]} \\
{[9,16]} \\
{[22,33,39]} \\
{[38]} \\
{[37,40]} \\
{[33]}\end{array}$ \\
\hline Consultant related & $\begin{array}{c}\text { Delays in payments } \\
\text { Underestimation of project cost } \\
\text { Poor inspection or supervision } \\
\text { Poor contract management } \\
\text { Delay in preparation and approval of drawings } \\
\text { Waiting time for approval of tests and inspections } \\
\text { Lack of competency and experience of consultant }\end{array}$ & $\begin{array}{c}{[5,41]} \\
{[37,40]} \\
{[15]} \\
{[40]} \\
{[5,38]} \\
{[33,37]} \\
{[9,20,33]}\end{array}$ \\
\hline Contractor related & $\begin{array}{c}\text { Poor site management } \\
\text { Financial problems/constraints } \\
\text { Construction methods } \\
\text { Poor planning (materials and labor estimation) } \\
\text { Poor communication and misunderstanding } \\
\text { Subcontractors (lack of experience, etc.) } \\
\text { Inadequate experience and competency of contractor }\end{array}$ & $\begin{array}{c}{[28,37]} \\
{[5,35,37]} \\
{[9,33]} \\
{[3,15,38]} \\
{[6,17,35]} \\
{[7,33]} \\
{[5,35,41]}\end{array}$ \\
\hline Government related & $\begin{array}{c}\text { Slow permits by government agencies } \\
\text { Bureaucracies in government agencies } \\
\text { Political interference } \\
\text { Economic conditions (currencies, inflation) } \\
\text { Ineffective legislative regulations }\end{array}$ & $\begin{array}{c}{[9,20]} \\
{[9]} \\
{[5,7]} \\
{[7,25]} \\
{[33]}\end{array}$ \\
\hline Materials related & $\begin{array}{c}\text { Shortage of construction materials } \\
\text { Escalation of material prices } \\
\text { Delay of material delivery on-site } \\
\text { Poor material procurement techniques } \\
\text { Low quality of materials }\end{array}$ & $\begin{array}{c}{[5,15]} \\
{[39]} \\
{[28,32,33]} \\
{[7,37]} \\
{[9,25,35]}\end{array}$ \\
\hline Contractual related & $\begin{array}{l}\text { Major claims and disputes } \\
\text { Inappropriate type of contract (procurement process) } \\
\text { Poor collaboration between parties }\end{array}$ & $\begin{array}{c}{[17]} \\
{[7,9,20]} \\
{[20,33]}\end{array}$ \\
\hline
\end{tabular}

independent of each other. The calculation of the Chi-Square statistic is quite straightforward and intuitive:

$$
x^{2}=\sum \frac{\left(f_{o}-f_{e}\right)^{2}}{f_{e}},
$$

where $f_{o}=$ the observed frequency (the observed counts in the cells) and $f_{e}=$ the expected frequency if no relationship existed between the variables.

As depicted in the formula, the Chi-Square statistic is based on the difference between what is actually observed in the data and what would be expected if there was truly no relationship between the variables.

3.6. Kendall's Coefficient of Concordance. Kendall's coefficient of concordance, also known as Kendall's W, is a measure of agreement among different stakeholders. Assume there are $m$ stakeholders rating $k$ factors in rank order from 1 to $k$. Let $r_{i j}=$ the rating stakeholder $j$ given to factor $i$.

For each factor $i$, let $R_{i}=\sum_{j=1}^{m} r_{i j}$. Let $\bar{R}$ be the mean of the $\mathrm{Ri}$ and let $R$ be the squared deviation, i.e.,

$$
R=\sum_{i=1}^{k}\left(R_{i}-\bar{R}\right)
$$

Kendall's W can be defined by

$$
W=\frac{12 R}{m^{2\left(k^{3}-k\right)}} .
$$

3.7. Spearman's Rank Correlation. Spearman's rank correlation is the nonparametric version of the Pearson rank correlation. Spearman's correlation coefficient $(\rho$, also signified by $r_{s}$ ) measures the strength and direction of association between two ranked variables. Spearman's rank correlation can be computed using the following formula:

$$
\rho=1-\frac{6 \sum d_{i}^{2}}{n\left(n^{2}-1\right)},
$$

where $\rho=$ Spearman rank correlation; $d_{i}=$ the difference between the ranks of corresponding variables; $n=$ number of observations. 


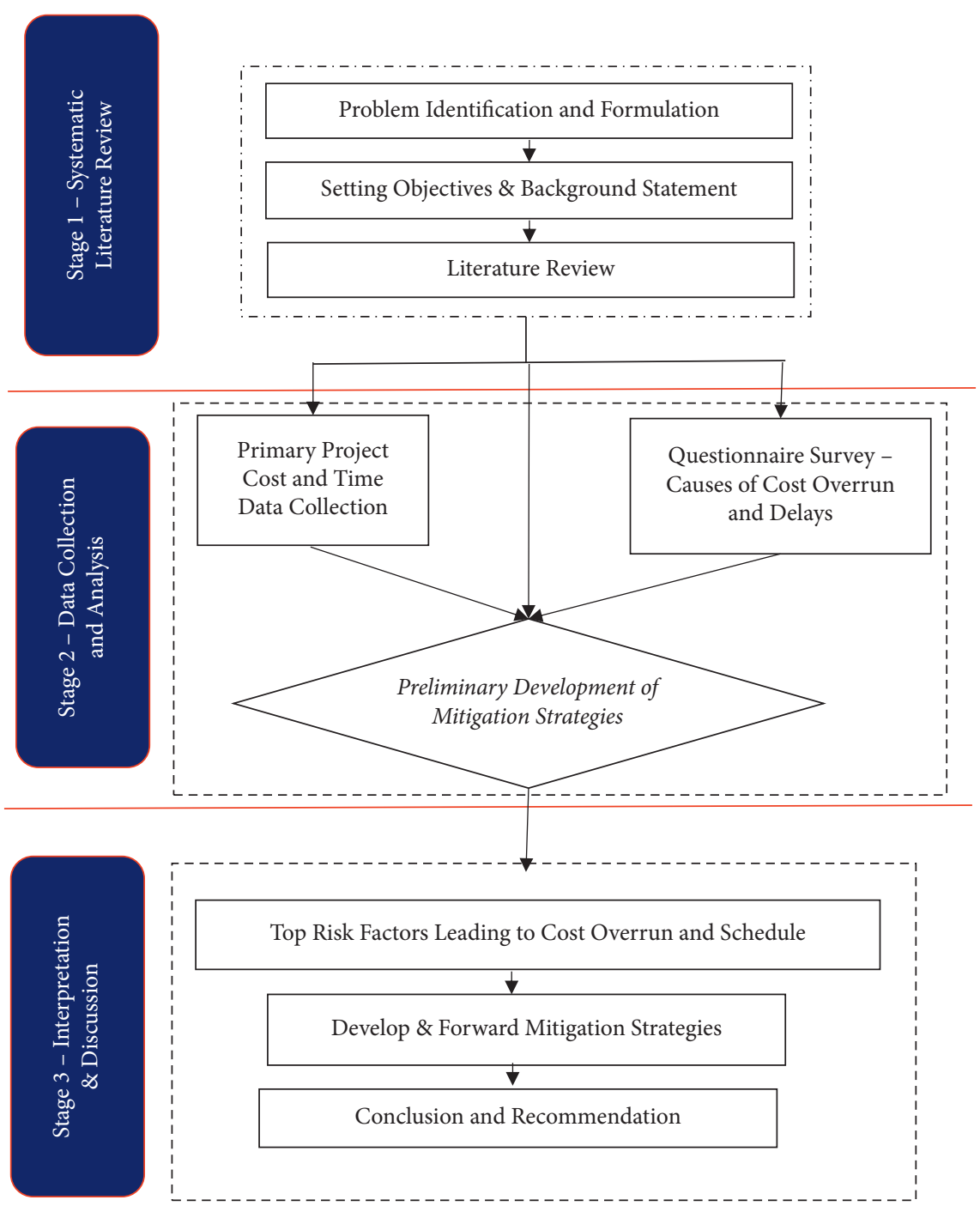

FIgURE 1: Research methodology flowchart.

\section{Findings}

This section describes the overall results obtained through various data collection methods and analyzed using statistical analysis tools.

\subsection{Cost Overrun in Construction Projects}

4.1.1. Building Projects. The first part of the analysis covers the cost data (contract amount and executed amount) of building construction projects collected throughout the country. The case studies involved for the analysis are illustrated in Table 3 below.

The first specific objective of this project work is to examine the extent of cost overrun and schedule delay in the Ethiopian building and road construction sectors. In this respect, for the cost overrun in building construction projects with contract amounts greater than 100 million, the minimum cost overrun for building projects is found to be $3 \%$ and the maximum amount is $71 \%$. The result also reveals that the average cost overrun of these projects is found to be
26\%. Similarly, the same computation has been done for contract amounts between 50 million and 100 million. In this case, the minimum cost overrun is found to be $4 \%$, whereas the maximum cost overrun of $105 \%$ is recorded accordingly. Hence, the average cost overrun value will be $35 \%$. Finally, for building construction projects with contract amounts $<50$ mil, the minimum, maximum, and average cost overruns are $2 \%, 42 \%$, and $248 \%$, respectively.

4.2. Road Infrastructure Projects. For the case of road projects, representative project data were collected mainly from the Ethiopian Road Authority (ERA). More so, additional road project data is also collected from Addis Ababa City Road Authority (ACRA), and the remaining data is collected using questionnaire survey from various contractors, clients, and consultants (Table 4).

For road construction projects, the minimum recorded cost overrun is $1 \%$ and the maximum cost overrun is found to be $61 \%$. On average, the cost overrun for road projects is computed as $18 \%$. 
TABLE 3: Cost data for building construction projects.

\begin{tabular}{|c|c|c|}
\hline Project & Contract amount & Cost overrun (\%) \\
\hline Medical faculty dormitory lot 2 & $498,310,069.60$ & 16 \\
\hline Medical faculty dormitory building lot 1 & $496,173,245.40$ & 8 \\
\hline Auditorium building & $370,264,019.53$ & 10 \\
\hline ICT building & $335,260,766.15$ & 37 \\
\hline Ethiopian institute of textile and fashion technology lot I & $277,910,931.26$ & 18 \\
\hline Sport academy & $190,226,678.00$ & 30 \\
\hline Medical faculty dormitory building lot 3 library and café & $179,124,014.60$ & 28 \\
\hline Gondar university expansion & $150,382,372.74$ & 71 \\
\hline BIT library building lot II & $130,153,029.48$ & 46 \\
\hline Awi zone administration office & $120,607,551.16$ & 6 \\
\hline Preclinical laboratory & $116,022,883.93$ & 43 \\
\hline EiTEX class room and clinic & $115,433,696.00$ & 16 \\
\hline Oromo public office building & $106,031,742.33$ & 3 \\
\hline Kombolcha city administration & $99,259,111.12$ & 6 \\
\hline Gondar university expansion lot II & $98,592,813.82$ & 47 \\
\hline ANRS trading industry development office in Gondar & $91,188,136.36$ & 29 \\
\hline Dormitory building for IOTEX lot 1 & 89718604.82 & 40 \\
\hline ANRS trading industry development office in Bahir Dar & $89,002,144.52$ & 27 \\
\hline Medical dormitory building & $85,314,737.00$ & 15 \\
\hline Medium industrial complex building & $79,294,031.64$ & 28 \\
\hline East Gojjam high court & $78,841,316$ & 79 \\
\hline Industry complex & $77,393,169.15$ & 23 \\
\hline Medium and higher industrial shade & $77,393,155.16$ & 85 \\
\hline Staff condominium lot II & $76,980,110.79$ & 105 \\
\hline Agricultural and science dormitory & 74260442.7 & 54 \\
\hline IOT class room and laboratory & 67942872.39 & 9 \\
\hline BIT class room and laboratory & $66,783,018.96$ & 4 \\
\hline Condominium phase II & $56,642,580.71$ & 20 \\
\hline Industry and urban development office & $55,796,487.28$ & 12 \\
\hline Debre Birhan industrial shade & $55,796,487.28$ & 17 \\
\hline Staff apartment II & $50,995,495.00$ & 25 \\
\hline Medical faculty staff apartment I & $50,568,855.00$ & 25 \\
\hline Bibugn primary hospital & $47,446,951.37$ & 7 \\
\hline Staff condominium lot I & $44,015,747.96$ & 16 \\
\hline AHWCE office & $40,979,133.33$ & 43 \\
\hline Debretabor administration office & $40,154,960.66$ & 54 \\
\hline Integrated land office (Amhara) & $39,965,322.64$ & 18 \\
\hline $\mathrm{G}+4$ integrated land office in Gondar & $39,965,322.64$ & 25 \\
\hline Class rooms and lecture hall & $32,850,712.29$ & 42 \\
\hline OR center renovation & $31,996,029.80$ & 248 \\
\hline Wegeda secondary hospital & $19,392,266.86$ & 4 \\
\hline Gondar industry and urban development office & $18,369,865.46$ & 2 \\
\hline Students dormitory & $12,491,518.24$ & 28 \\
\hline ANRS education office Dessie & $11,516,771.14$ & 39 \\
\hline Store and office buildings & $6,777,462.85$ & 46 \\
\hline
\end{tabular}

\subsection{Schedule Delays in Construction Projects}

4.3.1. Building Projects. The second specific objective of this project work is to compute the extent of schedule delays in both building and road construction projects. Similar to the previous computations, project contract and completion data were collected for building construction projects throughout the country. The time data for building projects with various contract amounts is shown in Table 5 .

For infrastructure construction projects that have contract amounts greater than 100 million, the result illustrated that the minimum delay is $41 \%$, whereas the maximum schedule delay is computed to be $327 \%$. Finally, the average schedule delay is found to be $175 \%$. In the case of building projects with contract amounts between 50 million and 100 million, the minimum project schedule is $11 \%$ and the maximum delay is $300 \%$.

Moreover, the average schedule delay for these projects is found to be $114 \%$. Further, the schedule delay for building projects with contract amounts less than 50 million ETB is computed as per the project time data presented in Table 5. From the computations, the minimum, maximum, and average schedule delays are $9 \%, 802 \%$, and $153 \%$, respectively. In general, after taking into account all building construction projects, the minimum, maximum, and average schedule delays are $9 \%, 802 \%$, and $143 \%$, respectively. 
TABle 4: Cost data for road projects in Ethiopia.

\begin{tabular}{|c|c|c|}
\hline Projects & Project cost & Cost overrun (\%) \\
\hline Meri, Shashemene, Hawassa & 197170297.92 & 17 \\
\hline Dedebit, Adiremet & 810212552.61 & 17 \\
\hline Injibara, Chagni Pawi Junction, Fendika, Ayema & 1337718925.93 & 10 \\
\hline Kibremengist, Shakiso & 119673513.69 & 61 \\
\hline Koka, Adulala, Debrezeit & 613165000.00 & 29 \\
\hline Hawassa Chuko (Mombasa, A.A Corridor) & 965247145.48 & 25 \\
\hline Chenka, Dembidolo Road & 648548842.21 & 4 \\
\hline Ayira, Chanka Road & 669143993.90 & 1 \\
\hline Abi Adi, Fireweyni & 819419501.06 & 7 \\
\hline South f6 junction, $\mathrm{f} 4$ junction & 1399064061.64 & 5 \\
\hline Mekeranjo, Ayira & 633534840.48 & 4 \\
\hline Jimma, Mizan & 742938243.78 & 20 \\
\hline Dire Dawa, Melka Jebdu & 470000000.00 & 8 \\
\hline Abunepetros square, Pastor & 144440764.43 & 4.11 \\
\hline Dama Hotel, Hanamariam & 54214003 & 26.47 \\
\hline Gotera, Wellosefer & 30000000 & 8.17 \\
\hline Megenagna, Ayat & 224055813.1 & 18.32 \\
\hline Megenagna, Meskel Square, Torhiloch lot $1 \&$ lot 2 & 1162448901 & 4.49 \\
\hline Mekanisa roundabout, Addis & 36554500.46 & 13.95 \\
\hline Meskel flower, Bole Rwanda & 49587265.63 & 58.42 \\
\hline Shola Gebeya, Lemhotel, Anbessa Garage & 109512767.9 & 32.69 \\
\hline Winget Aseco Bridge & $154,485,787.41$ & 17.25 \\
\hline Yekatit 12 square, Afenchober, Semen Hotel & 36213579 & 50.04 \\
\hline Bedele, Metu Road Upgrading Project & $610,019,298.35$ & 16 \\
\hline Kombolcha, Burka & $1,588,240,440.60$ & 4 \\
\hline Tsegede Junction, Ketema Nigus & $516,442,158.88$ & 2 \\
\hline
\end{tabular}

4.4. Schedule Delays in Road Projects. The data for road construction projects were collected mainly from the Ethiopian Road Authority (ERA), and additional data were collected in ACCRA, Amhara Roads Authority, Oromia Engineering Corporation, and others. The project time data are presented in Table 6 below.

For road construction projects, the overall computation is similar to that of the building projects. Hence, the minimum schedule delay is $3 \%$, whereas the maximum delay is computed to be $312 \%$. In addition, the average schedule delay for the road construction projects in Ethiopia is found to be $110 \%$.

\subsection{Risk Factors Leading to Cost Overrun}

4.5.1. Mean Score Ranking. The first section of the analysis focuses on identifying the critical risks causing cost overrun in building and road construction projects. These risks could be arising from various aspects of the project life cycle. In this study, Mean Score ranking techniques have been employed to pinpoint the major risk factors leading to cost overrun in the Ethiopian construction sector. Table 7 presents the Mean Score analysis summary of cost overrun risk factors in the Ethiopian construction industry.

The result reveals that the top risks factors causing cost overrun in the building and road projects are inflation, inaccurate cost estimates, variations, unforeseeable fluctuation in material and labor prices, and availability of resources (labor, materials, and equipment).
4.6. Analysis of Agreement within the Rankings of Participant Groups. The levels of agreements or disagreements within the rankings of participants were analyzed using Kendall's coefficient of concordance $(W)$. The range of values of Kendall's coefficient of concordance $(W)$ is from 0 to 1 . However, if the number of items that are going to be ranked is larger than 7, Chi-Square test will be used. $W$ can be calculated using the following formula:

$$
W=\frac{\sum_{i=1}^{n}(R 1-R 2)^{2}}{n\left(n^{2}-1\right) / 12}
$$

where $n=$ number of items to be ranked; $R=$ average of rank assigned to all items.

Similarly, the Chi-Square values with degree of freedom $(n-1)$ is calculated as follows:

$$
\varphi^{2}=k(n-1) W,
$$

where $k$ number of respondents ranking the items; $n=$ number of items to be ranked.

The rule is that if the Chi-Square values of risks leading to cost overrun are larger than the critical value reading from the Chi-Square significance level table and the given degrees of freedom (df) value, then the null hypothesis (Ho) will be rejected.

The null hypothesis (Ho) is as follows: There is no relationship within the rankings of each participant groups.

Kendall's coefficient of concordance $(W)$ is computed to be 0.036 for all respondents. Significant values for all group of respondents is calculated to be 0.4 which is less 
TABle 5: Time data for building construction projects.

\begin{tabular}{|c|c|c|c|}
\hline \multirow{2}{*}{ Projects } & \multicolumn{3}{|c|}{ Project time } \\
\hline & Contract duration (days) & Time elapsed (delay) & $\%$ delayed \\
\hline Medical faculty dormitory lot 2 & 540 & 929 & 172 \\
\hline Medical faculty dormitory building lot 1 & 540 & 819 & 152 \\
\hline Auditorium building in Gondar & 900 & 1321 & 147 \\
\hline ICT building & 600 & 1604 & 267 \\
\hline EiTEX lot I & 540 & 765 & 142 \\
\hline EiTEX lot II & 540 & 697 & 129 \\
\hline Sport academy & 540 & 872 & 161 \\
\hline Medical faculty dormitory building lot 3 library & 475 & 593 & 125 \\
\hline Gondar university expansion & 540 & 1768 & 327 \\
\hline BIT library building lot II & 475 & 1535 & 323 \\
\hline Awi zone administration office & 1080 & 655 & 61 \\
\hline Preclinical laboratory & 540 & 1686 & 312 \\
\hline Ethiopia institute of textile \& fashion class room & 540 & 482 & 89 \\
\hline Oromo public office building & 915 & 379 & 41 \\
\hline Gambela university project I & 365 & 1,095 & 300 \\
\hline Gambela university project II & 150 & 45 & 30.00 \\
\hline Ethio-ICT village & 1,548 & 175 & 11.30 \\
\hline Kombolcha city administration & 1080 & 280 & 26 \\
\hline Gondar university expansion lot II & 480 & 1417 & 295 \\
\hline ANRS industry development office in Gondar & 590 & 296 & 50 \\
\hline Dormitories, building for IOTEX lot 1 & 510 & 640 & 125 \\
\hline ANRS industry development office in Bahir Dar & 590 & 470 & 80 \\
\hline Medical dormitory building & 540 & 784 & 145 \\
\hline Medium industrial complex building & 590 & 677 & 115 \\
\hline East Gojjam high court & 730 & 634 & 87 \\
\hline Industry complex & 590 & 553 & 94 \\
\hline Medium and higher industrial shade & 655 & 220 & 34 \\
\hline Staff condominium lot II & 540 & 641 & 119 \\
\hline Agricultural \& science dormitory and class room & 365 & 656 & 180 \\
\hline IOT class room and laboratory & 365 & 409 & 112 \\
\hline BIT class room and laboratory & 420 & 552 & 131 \\
\hline Condominium phase II & 420 & 530 & 126 \\
\hline Debre Birhan industrial shade & 655 & 120 & 18 \\
\hline Staff apartment (Bahir Dar) & 540 & 651 & 121 \\
\hline Medical faculty staff apartment I & 540 & 651 & 121 \\
\hline Bibugn primary hospital & 387 & 116 & 30 \\
\hline Staff condominium lot I & 540 & 641 & 119 \\
\hline AHWCE office & 300 & 185 & 62 \\
\hline Debretabor administration office & 730 & 400 & 55 \\
\hline Integrated land office (Amhara) & 730 & 357 & 49 \\
\hline $\mathrm{G}+4$ integrated land office in Gondar & 655 & 567 & 87 \\
\hline Class rooms and lecture hall & 270 & 880 & 326 \\
\hline OR center renovation & 240 & 1041 & 434 \\
\hline Students kitchen (Dire Dawa University) & 270 & 509 & 189 \\
\hline Wegeda Woreda secondary hospital & 540 & 189 & 35 \\
\hline ANRS Burie industry park & 150 & 13 & 9 \\
\hline Gondar industry and urban development office & 655 & 120 & 18 \\
\hline University students dormitory & 282 & 351 & 124 \\
\hline Students dormitory & 282 & 351 & 124 \\
\hline ANRS education office Dessie & 210 & 90 & 43 \\
\hline Store and office buildings & 180 & 1444 & 802 \\
\hline
\end{tabular}

than the allowable significance level $(0.05$ or $5 \%)$. Correspondingly, the Chi-Square values for all respondents is 4.046 , respectively. From the Chi-Square table, the critical value of degree of freedom $(\mathrm{df})=4$ and $p=0.001$ is 13.28. Hence, since the calculated Chi-Square values of all group of respondents is lower than the critical value, it can be concluded that there is no relationship within rankings of each respondent group; and then the null hypothesis will be accepted.

4.7. Analysis of Agreement between Participant Groups. Spearman's rank correlation coefficient $\left(r_{s}\right)$ was adopted to test the correlation between group of respondents on the sets 
TABLE 6: Time data for road construction projects.

\begin{tabular}{|c|c|c|c|}
\hline Road projects & Contract duration (days) & Time elapsed (delay) & Percentage (delay) (\%) \\
\hline Shekussen, Michola & 365 & 499 & 137 \\
\hline Meri, Shashemene, Hawassa & 770 & 924 & 120 \\
\hline Dedebit, Adiremet & 1095 & 501 & 46 \\
\hline Injibara, Chagni Pawi Junction, Fendika, Ayema & 913 & 721 & 79 \\
\hline Kibremengist, Shakiso & 540 & 1035 & 192 \\
\hline Koka, Adulala, Debrezeit & 730 & 330 & 45 \\
\hline Hawassa Chuko (Mombasa, A.A Corridor) & 730 & 756 & 104 \\
\hline Chenka, Dembidolo Road & 910 & 911 & 100 \\
\hline Ayira, Chanka Road & 910 & 620 & 68 \\
\hline Abi Adi, Fireweyni & 1095 & 799 & 73 \\
\hline South f6 junction, $\mathrm{f} 4$ junction & 1095 & 34 & 3 \\
\hline Mekeranjo, Ayira & 910 & 398 & 44 \\
\hline Jimma, Mizan & 1036 & 1832 & 177 \\
\hline Dire Dawa - Melka Jebdu & 548 & 377 & 69 \\
\hline Dolo Ojo Junction, Hargale & 730 & 366 & 50 \\
\hline Winget, Aseco Bridge & 330 & 718 & 217.58 \\
\hline Yekatit 12 square, Afenchober, Semen Hotel & 365 & 965 & 264.38 \\
\hline Dama Hotel, Hanamariam & 365 & 790 & 216.44 \\
\hline Megenagna, Meskel Square, Torhiloch lot $1 \&$ lot 2 & 550 & 176 & 32.00 \\
\hline Meskel flower, Bole Rwanda & 575 & 1,795 & 312.17 \\
\hline Shola Gebeya, Lemhotel, Anbessa Garage & 575 & 657 & 114.26 \\
\hline Mekanisa roundabout, Addis & 90 & 180 & 200.00 \\
\hline Abunepetros square, Pastuer & 224 & 539 & 240.63 \\
\hline Megenagna, Ayat & 420 & 289 & 68.81 \\
\hline Gotera, Wellosefer & 180 & 45 & 25.00 \\
\hline Gelan, Insilale, L/Dadhi & 1095 & 975 & 89 \\
\hline Sheno, Deneba & 2036 & 65 & 3 \\
\hline Kula, Dereba, Semar & 1300 & 460 & 35 \\
\hline Shambo town int. Asphalt & 450 & 1156 & 257 \\
\hline Hinde Bridge & 450 & 621 & 138 \\
\hline Kurbi, Giwe, Dado & 925 & 2400 & 259 \\
\hline Hidi, Lola, Sololo & 1095 & 120 & 11 \\
\hline Alge, Sachi, Mako, Degga & 730 & 850 & 116 \\
\hline Yayo, Elemo & 720 & 645 & 90 \\
\hline Gelila, Waja, Mender 10 & 1095 & 485 & 44 \\
\hline Bedele, Metu Road Upgrading Project & $1,080.00$ & 401.00 & 37 \\
\hline Kombolcha, Burka & $1,095.00$ & 187.00 & 17 \\
\hline Tsegede Junction, Ketema Nigus & 730.00 & 554.00 & 76 \\
\hline
\end{tabular}

of rankings. Normally, Spearman's rank correlation coefficient ranges from -1 to +1 . The higher the positive/negative value of $r_{s}$, the stronger the positive/negative linear correlation (relationship). In contract, if $r_{s}=0$, there is no linear relationship between two sets of rankings at all. The rule is that if $r_{s}$ is statistically significant at a predetermined significance level (i.e., 5\%), the null hypothesis (Ho) will be rejected.

The null hypothesis (Ho) in this is as follows: There is no correlation between the sets of rankings among participant groups.

$r_{s}$ can be computed using the following formula:

$$
r_{s}=\frac{6 \sum d^{2}}{n\left(n^{2}-1\right)},
$$

where $d=$ the difference between ranking of two groups in the same item; $n=$ total number of responses for an item.

The $r_{s}$ values for risks leading to cost overrun at the significant level of 0.05 , (a) between clients and contractor group, (b) client and consultants, and (d) consultant and contractor, are $0.119,0.699$, and 0.119 respectively. Similarly, the significant levels for the pair between client and contractor, client and consultant, and consultant and contractor are $0.545,0.051$, and 0.545 , respectively. All the calculated $\rho$ values are greater than the threshold value 0.05 . Hence, the null hypothesis will be accepted, which means that there is a no significant correlation between client and contractor group and client and consultant group on the overall ranking of risks leading to cost overrun in the Ethiopian public construction sector.

\subsection{Risk Factors Leading to Schedule Delay}

4.8.1. Mean Score Ranking. This section focuses on the critical risk factors leading to schedule delays in both building and road construction projects. These risks were initially collected using a systematic literature review and validated through content analysis before the main data collection. Consequently, the analysis is organized based on 
TABLE 7: Critical risks leading to cost overrun in construction projects.

\begin{tabular}{|c|c|c|c|c|c|c|c|c|c|c|}
\hline \multirow{3}{*}{ Critical risks leading to cost overrun } & \multicolumn{10}{|c|}{ Mean score } \\
\hline & \multicolumn{2}{|c|}{ Overall } & \multicolumn{2}{|c|}{ Contractor } & \multicolumn{2}{|c|}{ Consultant } & \multicolumn{2}{|c|}{ Client } & \multicolumn{2}{|c|}{ Academia } \\
\hline & $\begin{array}{l}\text { Mean } \\
\text { score }\end{array}$ & Rank & $\begin{array}{l}\text { Mean } \\
\text { score }\end{array}$ & Rank & $\begin{array}{l}\text { Mean } \\
\text { score }\end{array}$ & Rank & $\begin{array}{l}\text { Mean } \\
\text { score }\end{array}$ & Rank & $\begin{array}{l}\text { Mean } \\
\text { score }\end{array}$ & Rank \\
\hline Inflation & 4.43 & 1 & 4.46 & 3 & 4.42 & 25 & 4.33 & 25 & 4.50 & 25 \\
\hline Inaccurate cost estimates & 4.29 & 2 & 4.38 & 4 & 4.25 & 8 & 3.83 & 8 & 4.50 & 8 \\
\hline Variations & 4.24 & 3 & 4.08 & 9 & 4.08 & 3 & 4.33 & 3 & 4.17 & 3 \\
\hline $\begin{array}{l}\text { Unforeseeable fluctuation in material and } \\
\text { labor prices }\end{array}$ & 4.24 & 4 & 4.62 & 1 & 3.83 & 27 & 3.83 & 27 & 4.44 & 27 \\
\hline $\begin{array}{l}\text { Availability of resources (labor, materials, } \\
\text { and equipment) }\end{array}$ & 4.14 & 5 & 4.08 & 11 & 3.50 & 14 & 3.50 & 14 & 4.11 & 14 \\
\hline Delay in decision making & 4.10 & 6 & 3.92 & 12 & 3.92 & 4 & 3.33 & 4 & 4.17 & 4 \\
\hline Market conditions/economic climate & 4.10 & 7 & 4.54 & 2 & 4.00 & 23 & 3.50 & 23 & 3.89 & 23 \\
\hline Political situation of the country & 4.10 & 8 & 4.15 & 8 & 3.58 & 24 & 2.83 & 24 & 4.11 & 24 \\
\hline Delay in payment of completed works & 3.95 & 9 & 4.15 & 6 & 3.42 & 2 & 3.00 & 2 & 4.33 & 2 \\
\hline $\begin{array}{l}\text { Lack of coordination and communication } \\
\text { between parties }\end{array}$ & 3.95 & 10 & 3.85 & 13 & 4.17 & 5 & 3.50 & 5 & 4.28 & 5 \\
\hline Poor supervision and contract management & 3.86 & 11 & 4.15 & 7 & 4.25 & 7 & 3.17 & 7 & 4.11 & 7 \\
\hline $\begin{array}{l}\text { Clarity and accuracy of project information } \\
\text { before execution }\end{array}$ & 3.86 & 12 & 4.08 & 10 & 3.50 & 11 & 3.50 & 11 & 3.67 & 11 \\
\hline Financial status of client & 3.81 & 13 & 3.69 & 18 & 3.67 & 1 & 3.83 & 1 & 4.06 & 1 \\
\hline Complexity of design and construction & 3.81 & 14 & 3.15 & 25 & 3.50 & 12 & 3.83 & 12 & 3.61 & 12 \\
\hline $\begin{array}{l}\text { Changes in project schedule and phasing } \\
\text { requirements }\end{array}$ & 3.80 & 15 & 3.62 & 20 & 3.92 & 17 & 3.83 & 17 & 4.17 & 17 \\
\hline Poor feasibility and project analysis & 3.71 & 16 & 4.23 & 5 & 4.08 & 9 & 3.00 & 9 & 4.39 & 9 \\
\hline $\begin{array}{l}\text { Level of workmanship (productivity and } \\
\text { performance) }\end{array}$ & 3.70 & 17 & 3.83 & 16 & 3.67 & 22 & 3.33 & 22 & 3.78 & 22 \\
\hline $\begin{array}{l}\text { Competency and experience of consulting } \\
\text { firm }\end{array}$ & 3.57 & 18 & 3.85 & 14 & 3.17 & 6 & 3.50 & 6 & 3.83 & 6 \\
\hline Government regulations & 3.48 & 19 & 3.23 & 24 & 3.42 & 26 & 3.33 & 26 & 3.61 & 26 \\
\hline Availability of machinery & 3.48 & 20 & 3.77 & 17 & 3.00 & 28 & 2.33 & 28 & 3.44 & 28 \\
\hline Site constraints (access, storage, electricity) & 3.43 & 21 & 3.54 & 21 & 3.33 & 16 & 3.17 & 16 & 3.17 & 16 \\
\hline Clear and detailed drawings and specification & 3.38 & 22 & 3.62 & 19 & 3.42 & 10 & 3.50 & 10 & 3.61 & 10 \\
\hline $\begin{array}{l}\text { Project delivery method and contractual } \\
\text { arrangement }\end{array}$ & 3.38 & 23 & 3.85 & 15 & 3.33 & 19 & 3.17 & 19 & 3.11 & 19 \\
\hline Quality of information flow during execution & 3.29 & 24 & 3.46 & 22 & 3.50 & 13 & 3.17 & 13 & 3.61 & 13 \\
\hline Type of currency used & 3.00 & 25 & 3.38 & 23 & 3.08 & 18 & 2.83 & 18 & 3.29 & 18 \\
\hline Advance payment arrangement & 2.90 & 26 & 3.00 & 27 & 3.33 & 20 & 3.00 & 20 & 2.94 & 20 \\
\hline Type and value of insurance & 2.71 & 27 & 2.85 & 28 & 3.25 & 21 & 3.33 & 21 & 2.72 & 21 \\
\hline $\begin{array}{l}\text { Type of project (residential, commercial, } \\
\text { industrial, etc.) }\end{array}$ & 2.67 & 28 & 3.00 & 26 & 2.75 & 15 & 3.50 & 15 & 2.94 & 15 \\
\hline
\end{tabular}

the perception of major stakeholders: overall, contractor, consultant, owner, and academia, as shown in Table 8.

The result reveals that the top risks factors causing delays in the building and road projects are variations (design changes/extra work), economic conditions (currency, inflation), escalation of material prices, shortage of construction materials, delay in payments, financial constraints, delay in preparation and approval of drawings, poor site management, and poor planning.

\section{Discussion and Practical Implications}

The aim of this study was to examine the extent of cost overrun and schedule delays, including the investigation of the critical causes of both challenges in low income countries using 52 respondents. Multiple data collection and analysis tools were deployed to provide key project data and practical implications for various stakeholders, including policy makers and the regulatory body.

The first section of the analysis reveals that an average cost overrun of $35 \%$ for building and $18 \%$ for road infrastructure projects were recorded throughout the Ethiopian construction industry. This is also evident in various developing and developed countries $[3,5,39]$. The present study also explored the extent of schedule delays in the Ethiopian infrastructure construction sector using first hand project information across the country. The case studies were analyzed after taking into account all building construction projects; and the average schedule delay of $143 \%$ is recorded. For road construction projects, the overall computation is similar to that of the building projects. Hence, the average schedule delay for these infrastructure projects in Ethiopia is found to be $110 \%$. 
TABLE 8: Critical risks leading to schedule delays in construction projects.

\begin{tabular}{|c|c|c|c|c|c|c|c|c|c|c|}
\hline \multirow{3}{*}{ Critical risks leading to schedule delay } & \multicolumn{10}{|c|}{ Mean score } \\
\hline & \multicolumn{2}{|c|}{ Overall } & \multicolumn{2}{|c|}{ Contractor } & \multicolumn{2}{|c|}{ Consultant } & \multicolumn{2}{|c|}{ Client } & \multicolumn{2}{|c|}{ Academia } \\
\hline & $\begin{array}{l}\text { Mean } \\
\text { score }\end{array}$ & Rank & $\begin{array}{l}\text { Mean } \\
\text { score }\end{array}$ & Rank & $\begin{array}{l}\text { Mean } \\
\text { score }\end{array}$ & Rank & $\begin{array}{l}\text { Mean } \\
\text { score }\end{array}$ & Rank & $\begin{array}{c}\text { Mean } \\
\text { score }\end{array}$ & Rank \\
\hline Variations (design changes/extra work) & 4.71 & 1 & 4.55 & 9 & 4.33 & 3 & 4.50 & 1 & 4.56 & 1 \\
\hline Economic conditions (currency, inflation) & 4.48 & 2 & 4.92 & 1 & 4.75 & 1 & 4.67 & 3 & 4.50 & 2 \\
\hline Escalation of material prices & 4.48 & 3 & 4.58 & 8 & 4.25 & 5 & 4.17 & 5 & 4.50 & 4 \\
\hline Shortage of construction materials & 4.38 & 4 & 4.58 & 5 & 4.42 & 2 & 4.67 & 2 & 4.17 & 3 \\
\hline Delay in payments & 4.33 & 5 & 4.25 & 3 & 3.83 & 9 & 3.50 & 21 & 4.22 & 5 \\
\hline Financial problems/constraints & 4.33 & 6 & 4.67 & 14 & 4.08 & 17 & 3.50 & 22 & 4.17 & 17 \\
\hline $\begin{array}{l}\text { Delay in preparation and approval of } \\
\text { drawings }\end{array}$ & 4.29 & 7 & 4.25 & 15 & 4.33 & 4 & 3.67 & 17 & 4.06 & 26 \\
\hline Poor site management & 4.24 & 8 & 4.58 & 4 & 4.17 & 6 & 3.50 & 12 & 3.83 & 15 \\
\hline $\begin{array}{l}\text { Poor planning (material and labor } \\
\text { estimation) }\end{array}$ & 4.24 & 9 & 4.67 & 6 & 4.17 & 7 & 3.83 & 23 & 4.00 & 29 \\
\hline Construction methods & 4.14 & 10 & 4.33 & 2 & 3.83 & 12 & 3.50 & 4 & 4.06 & 6 \\
\hline Delay of material delivery on-site & 4.14 & 11 & 4.75 & 12 & 3.92 & 18 & 4.50 & 24 & 4.11 & 9 \\
\hline $\begin{array}{l}\text { Unrealistic contract durations imposed by } \\
\text { owner }\end{array}$ & 4.1 & 12 & 4.25 & 10 & 3.75 & 13 & 3.50 & 25 & 4.00 & 23 \\
\hline Underestimation of project cost & 4.1 & 13 & 4.42 & 16 & 3.92 & 22 & 3.17 & 31 & 4.11 & 30 \\
\hline Poorly defined project scope & 4.05 & 14 & 4.42 & 7 & 4.00 & 10 & 3.67 & 10 & 4.17 & 13 \\
\hline Slow decision making by owners & 4.05 & 15 & 4.58 & 11 & 3.75 & 23 & 4.00 & 18 & 3.89 & 31 \\
\hline Poor communication between project team & 4 & 16 & 4.08 & 19 & 3.92 & 14 & 4.17 & 6 & 3.94 & 7 \\
\hline $\begin{array}{l}\text { Inadequate experience and competency of } \\
\text { contractor }\end{array}$ & 4 & 17 & 4.00 & 21 & 3.83 & 19 & 4.17 & 7 & 3.72 & 14 \\
\hline Lack of experience of consulting firm & 3.95 & 18 & 3.83 & 25 & 4.17 & 8 & 3.33 & 28 & 3.56 & 32 \\
\hline $\begin{array}{l}\text { Waiting time for approval of tests and } \\
\text { inspections }\end{array}$ & 3.86 & 19 & 3.83 & 13 & 4.00 & 11 & 3.50 & 8 & 3.78 & 10 \\
\hline $\begin{array}{l}\text { Poor communication and } \\
\text { misunderstandings }\end{array}$ & 3.86 & 20 & 4.17 & 17 & 3.75 & 24 & 3.83 & 13 & 3.89 & 11 \\
\hline Bureaucracy in government agencies & 3.86 & 21 & 4.33 & 22 & 3.58 & 27 & 4.17 & 26 & 4.17 & 22 \\
\hline Poor collaboration between major parties & 3.86 & 22 & 4.00 & 26 & 3.67 & 32 & 3.00 & 32 & 3.94 & 27 \\
\hline Subcontractors (lack of experience, etc.) & 3.76 & 23 & 4.09 & 18 & 3.67 & 20 & 3.67 & 14 & 3.61 & 8 \\
\hline Poor material procurement techniques & 3.76 & 24 & 4.08 & 20 & 3.83 & 28 & 3.83 & 19 & 4.11 & 24 \\
\hline Owner interference & 3.71 & 25 & 3.91 & 23 & 3.67 & 15 & 3.83 & 9 & 3.78 & 16 \\
\hline Poor inspection/supervision & 3.71 & 26 & 3.75 & 24 & 3.75 & 25 & 3.50 & 15 & 4.11 & 18 \\
\hline Ineffective legislative regulations & 3.71 & 27 & 3.67 & 29 & 3.67 & 29 & 4.17 & 27 & 3.94 & 20 \\
\hline Major claims and disputes & 3.71 & 28 & 3.92 & 30 & 3.92 & 30 & 3.33 & 29 & 3.53 & 25 \\
\hline $\begin{array}{l}\text { Inappropriate type of contract } \\
\text { (procurement process) }\end{array}$ & 3.67 & 29 & 3.83 & 27 & 3.67 & 31 & 3.33 & 30 & 3.78 & 28 \\
\hline Slow permits by government agencies & 3.62 & 30 & 3.83 & 28 & 3.83 & 21 & 3.83 & 11 & 3.67 & 12 \\
\hline Political interference & 3.62 & 31 & 3.67 & 31 & 3.75 & 26 & 4.00 & 16 & 3.56 & 19 \\
\hline Low quality of materials & 3.48 & 32 & 3.33 & 32 & 3.92 & 16 & 3.67 & 20 & 3.72 & 21 \\
\hline
\end{tabular}

Similarly, this paper explored the critical risk factors leading to cost overrun and schedule delays in Ethiopia. The result showed that variations (design changes/extra work) [Mean Score - 4.71] is the top risk factor contributing to schedule delays in both building and road construction projects. Variation in the construction industry is related to design changes and extra work that was not initially clustered in the first design. The result is in line with the findings of $[39,49]$.

The second top delay risk factor with a Mean Score of 4.48 is economic conditions (currency, inflation). The result is in line with similar studies conducted in Algeria and UAE $[50,51]$. The construction sector is one of the major resource intensive industries that take up a huge amount of countries' budget for infrastructure construction [42]. Economic inflation and unexpected variations in prices of construction materials including equipment and fluctuations in foreign currency exchange rates disrupt the performance of infrastructure construction projects, which in turn leads to schedule delays and disputes among major construction parties $[8,40]$. The remaining top risk factors causing schedule delays are escalation of material prices [Mean Score - 4.48], shortage of construction materials [Mean Score - 4.38], and delay in interim payments [Mean Score - 4.33]. These risk factors are all interrelated and need proper attention to alleviate the challenges caused by project delay, particularly in the planning, design, and construction stages of the project life cycle.

Further, the analysis covers risk factors leading to cost overrun in infrastructure projects. In this respect, the top risk factor leading to cost overrun in construction projects across the Ethiopian construction industry is found to be 
TABLE 9: Critical recommended actions to reduce cost overrun and delay.

Stakeholder Key recommended actions (checklists)

(i) Client should allocate proper budget as per the cost estimation including contingency

(ii) Owner should appoint a separate construction management consultant for quick decision making, particularly for major

Client projects

(iii) Scope of projects shall be adequately defined

(iv) Reduce variations and change orders after comment of projects

(i) Resource planning, including equipment and labor, should be done as per project milestone and duration

(ii) Provide various capacity building trainings and motivation incentives for workers

Contractor (iii) Develop proper work methodology to improve productivity of labors and equipment

(iv) Develop project specific hierarchical structure to facilitate decision making between project team

(v) Use appropriate innovations and technologies to improve performance of infrastructure projects

(i) Provide complete design and cost estimation as per the requirement by owners

Consultant (ii) Develop mechanisms to solve disputes between client and contractor

(iii) Develop project specific strategies to monitor progress of projects and inspect key developments

(iv) Approve interim payments and design changes in line with contract documents and specifications

inflation [Mean Score - 4.43]. Prior studies reported the negative impacts of inflation in the delivery and success of construction projects. For instance, Le-Hoai et al. in Vietnam elaborated that price inflation causes fluctuation of material and labor prices [52], whereas Abusafiya and Suliman discussed the effect of inflation and design change in const overrun and delays in Bahrain construction industry [47].

The second top risk factor is inaccurate cost estimates [Mean Score - 4.29]. Accurately estimating cost of infrastructure projects is critical for budgetary purposes. Consulting and design firms are responsible for estimating all the required costs immediately after completing all designs, before the preparation of tender documents. Omoush reported that inaccurate cost estimates can disrupt the overall performance of construction projects and ultimately create major court disputes between various project teams involving in infrastructure undertaking [53]. Similarly, the findings of this study also illustrated that variations [Mean Score - 4.24], unforeseeable fluctuation in material and labor prices [Mean Score - 4.24], and availability of resources (labor, materials, and equipment) [Mean Score - 4.14] greatly influence cost performance of infrastructure projects in the construction business environment. Table 9 presents the key recommended actions to improve cost overrun and reduce schedule delay in infrastructure projects.

\section{Conclusion}

The aim of this study was to examine the extent and risks leading to cost overrun and schedule delays in construction projects. Further, the study provided benchmarking key recommended actions (check lists) for major stakeholders to alleviate the critical risks imposed by project cost overrun and the associated schedule delays across various infrastructures in the Ethiopian construction market.

The results highlighted the degree of cost overrun and delay in both building and road infrastructure projects. In addition, the findings summarized the top key risk factors leading to cost overrun and schedule delays in construction projects. Further, this study for the first time contributed critical practical implications and checklists for key stakeholders to improve the overall cost and time performances of infrastructure projects in the Ethiopian construction sector.

The findings of this study will have meaningful positive impact for various practitioners and stakeholders in construction. Reducing and improving cost overruns and schedule delays is vital to ensure the success of infrastructure projects in any country. It is important to denote that both cost and time management are crucial project performance tools and indicators. The first step to devise important methodologies and steps for performance improvement is by exploring the extent of the problems and by identifying the root causes and critical risk factors leading to cost overrun and delay.

The study has a few limitations: (1) Although it might be beneficial to understand the impacts of both cost overrun and schedule delays in particular cases of different project types, this analysis does not consider the type of projects, such as residential, commercial, healthcare, and so on, and (2) it does not consider the contract amounts for road infrastructure projects, as the values are concentrated in similar amounts. Future studies could focus on investigating the relationship between cost overrun and schedule delays with project performance and success from the perspectives of small and medium sized enterprises to large corporations [54].

\section{Data Availability}

The data underlying the results presented in the study are available within the manuscript.

\section{Conflicts of Interest}

The authors declare no conflicts of interest.

\section{Acknowledgments}

This project was funded by the Construction Works Regulatory Authority of Ethiopia (CWRA/LB/008/2013). 


\section{References}

[1] S. Belay, J. Goedert, A. Woldesenbet, and S. Rokooei, "Enhancing BIM implementation in the Ethiopian public construction sector: an empirical study," Cogent Engineering, vol. 8, no. 1, pp. 1886476-1886527, 2021.

[2] E. L. C. Osabutey and Z. Jin, "Factors influencing technology and knowledge transfer: configurational recipes for SubSaharan Africa," Journal of Business Research, vol. 69, no. 11, pp. 5390-5395, 2016.

[3] J. S. Jongo, D. N. G. A. K. Tesha, R. Kasonga, J. J. Teyanga, and K. S. Lyimo, "Mitigation measures in dealing with delays and cost overrun in public building projects in dar-Es-salaam, Tanzania," International Journal of Construction Engineering and Management, vol. 8, no. 3, pp. 81-96, 2019.

[4] D. D. Ahiaga-Dagbui, P. E. D. Love, S. D. Smith, and F. Ackermann, "Toward a systemic view to cost overrun causation in infrastructure projects: a review and implications for research," Project Management Journal, vol. 48, no. 2, pp. 88-98, 2017.

[5] V. G. M. Luvara, S. Phoya, D. N. G. A. K. Tesha, and K. S. Lyimo, "Critical factors causing delay and cost overrun in public building projects in dar es salaam, Tanzania," Indian Journal Research, vol. 7, no. 7, 2018.

[6] A. Khan, M. Choudhary, S. Khushnood, and S. Masood, "Development of econometric models for cost \& time overruns: an empirical study of major road construction projects in Pakistan," University of Engineering Technology Taxila Technical Journal, vol. 20, no. 4, p. 79, 2015.

[7] N. T. Adugna, A Study of Causes of Delay and Cost Overrun in Office Construction Projects in the eThekwini Municipal Area, pp. 1-136, Durban University of Technology, Durban, South Africa, 2015.

[8] R. Derakhshanalavijeh and J. M. C. Teixeira, "Cost overrun in construction projects in developing countries, Gas-Oil industry of Iran as a case study," Journal of Civil Engineering and Management, vol. 23, no. 1, pp. 125-136, 2016.

[9] R. K. Shah, "An exploration of causes for delay and cost overrun in construction projects: a case study of Australia, Malaysia \& Ghana," Journal of Advanced College of Engineering and Management, vol. 2, 2016.

[10] I. Abdul Rahman, A. Hameed Mem, and A. Tarmizi Abd.Karim, "Significant factors causing cost overruns in large construction projects in Malaysia," Journal of Applied Sciences, vol. 13, no. 2, pp. 286-293, 2013.

[11] S. Belay, J. Goedert, A. Woldesenbet, and S. Rokooei, "A hybrid delphi-AHP based analysis of construction project specific success factors in emerging markets: the case of Ethiopia," Cogent Engineering, vol. 8, no. 1, pp. 1891701-1891723, 2021.

[12] Z. Alias, E. M. A. Zawawi, K. Yusof, and N. M. Aris, "Determining critical success factors of project management practice: a conceptual framework," Procedia - Social and Behavioral Sciences, vol. 153, pp. 61-69, 2014.

[13] M. M. Mukhtar, R. B. Amirudin, T. Sofield, and I. B. Mohamad, "Critical success factors for public housing projects in developing countries: a case study of Nigeria," Environment, Development and Sustainability, vol. 19, no. 5, pp. 2039-2067, 2017.

[14] E. G. Sinesilassie, S. Z. S. Tabish, and K. N. Jha, "Critical factors affecting cost performance: a case of Ethiopian public construction projects," International Journal of Construction Management, vol. 18, no. 2, pp. 108-119, 2018.
[15] T. Umar, "Causes of delay in construction projects in Oman," Middle East Journal of Management, vol. 5, no. 2, p. 121, 2018.

[16] K. Dinesh, "Causes and effects of delays in Indian construction projects," International Research Journal of Engineering and Technology, vol. 3, no. 4, pp. 1831-1837, 2016, Online]. Available: http://www.irjet.net.

[17] T. Pourrostam and A. Ismail, "Causes and effects of delay in Iranian construction projects," International Journal of Engineering \& Technology, vol. 4, no. 5, pp. 598-601, 2012.

[18] M. Kesavan, R. Gobishanker, N. N. Gobidan, and P. B. G. Dissanayake, "Proper project planning in avoiding construction project delays," in Proceedings of the 5th International Conference on Sustainable Built Environment, pp. 256-265, Berlin, Germany, 2015.

[19] N. N. K. Nik Mohd Ainul Azman, A. Che Ahmad, M. Mohd Derus, and I. F. Mohd Kamar, "Determination of direct to indirect accident cost Ratio for railway construction project," MATEC Web of Conferences, vol. 266, Article ID 03009, 2019.

[20] Y. Frimpong, J. Oluwoye, and L. Crawford, "Causes of delay and cost overruns in construction of groundwater projects in a developing countries; Ghana as a case study," International Journal of Project Management, vol. 21, no. 5, pp. 321-326, 2003.

[21] G. A. Niazi and N. Painting, "Significant factors causing cost overruns in the construction industry in Afghanistan," Procedia Engineering, vol. 182, pp. 510-517, 2017.

[22] N. Al-Hazim, Z. A. Salem, and H. Ahmad, "Delay and cost overrun in infrastructure projects in Jordan," Procedia Engineering, vol. 182, pp. 18-24, 2017.

[23] Y. I. Park and T. C. Papadopoulou, "Causes of cost overruns in transport infrastructure projects in Asia," Built Environment Project and Asset Management, vol. 2, no. 2, pp. 195-216, 2012.

[24] A. H. Memon, I. A. Rahman, N. Y. Zainun, and A. T. A. Karim, "Web-based risk assessment technique for time and cost overrun (wrattco) - a framework," Procedia Social and Behavioral Sciences, vol. 129, pp. 178-185, 2014.

[25] E. Sinesilassie, S. Tabish, and K. Jha, "Critical factors affecting schedule performance: a case of Ethiopian public construction projects - engineers' perspective," Engineering Construction and Architectural Management, vol. 22, no. 1, pp. 91-107, 2017.

[26] A. Shiferaw Belachew, "Causes of cost overrun in federal road projects of Ethiopia in case of southern district," American Journal of Civil Engineering, vol. 5, no. 1, p. 27, 2017.

[27] A. Hameed Memon, I. A. Rahman, M. R. Abdullah, A. Asmi, and A. Azis, "Factors affecting construction cost performance in project management projects: case of MARA large projects," International Journal of Civil Engineering Built Environ.vol. 1, no. 1, pp. 2289-6317, 2014.

[28] Z. Shehu, I. R. Endut, and A. Akintoye, "Factors contributing to project time and hence cost overrun in the Malaysian construction industry," Journal of Financial Management of Property and Construction, vol. 19, no. 1, pp. 55-75, 2014.

[29] T. A. Amri and M. Marey-Pérez, "Towards a sustainable construction industry: delays and cost overrun causes in construction projects of Oman," Journal of Project Management, vol. 5, pp. 87-102, 2020.

[30] A. Alhomidan, "Factors affecting cost overrun in road construction projects in Saudi arabia," International Journal of Civil Environmental Engineering IJCEE-IJENS IJENS I J E N S, vol. 13, no. 3, pp. 1-4, 2013.

[31] I. Mahamid and N. Dmaidi, "Risks leading to cost overrun in building construction from consultants' perspective," 
Organization, Technology \& Management in Construction: An International Journal, vol. 5, no. 2, pp. 860-873, 2013.

[32] C. B. Venkateswaran, R. Murugasan, and R. Murugasan, "Time delay and cost overrun of road over bridge (ROB) construction projects in India," Journal of Construction in Developing Countries, vol. 22, no. 1, pp. 79-96, 2017.

[33] A. Enshassi, J. Al-Najjar, and M. Kumaraswamy, "Delays and cost overruns in the construction projects in the Gaza Strip," Journal of Financial Management of Property and Construction, vol. 14, no. 2, pp. 126-151, 2009.

[34] M. Aftab Hameed, R. Ismail Abdul, and A. Ade Asmi Abdul, "Preliminary study on causative factors leading to construction cost overrun," Int. J. Sustain. Constr. Eng. Technol.vol. 2, no. 1, pp. 57-71, 2011, [Online]. Available: http://penerbit.uthm.edu. my/ojs/index.php/IJSCET/article/viewFile/49/65.

[35] S. Ashwini Arun, "Effect of construction delays on project time overrun: Indian scenario," International Journal of Renewable Energy Technology, vol. 3, no. 1, pp. 543-547, 2014.

[36] A. Ade Asmi Abdul, M. Aftab Hameed, R. Ismail Abdul, and A. Ahmad Tarmizi, "Controlling cost overrun factors in construction projects in Malaysia," Research Journal of Applied Sciences, Engineering and Technology, vol. 5, no. 8, pp. 2621-2629, 2013.

[37] J.-B. Yang and P.-R. Wei, "Causes of delay in the planning and design phases for construction projects," Journal of Architectural Engineering, vol. 16, no. 2, pp. 80-83, 2010.

[38] J. Y. Altarawneh, V. Thiruchelvam, and B. Samadi, "Analysis of critical success factors influence on critical delays for water infrastructure construction projects in the abu dhabi emirate using PLS-SEM method," International Business Research, vol. 11, no. 2, p. 16, 2018.

[39] H. D. Wuala and A. D. Rarasati, "Causes of delays in construction project for developing Southeast Asia countries," IOP Conference Series: Materials Science and Engineering, vol. 830, no. 2, Article ID 022054, 2020.

[40] N. Serani, D. Tadele, and W. Bayeh, "The causes and effects of delay of building construction in Ethiopia, southern nation nationalities of people region in gurage zone (case of wolkite town)," Civil and Environmental Research, vol. 5790, pp. 12-21, 2020.

[41] T. Gebrehiwet and H. Luo, "Analysis of delay impact on construction project based on RII and correlation coefficient: empirical study," Procedia Engineering, vol. 196, pp. 366-374, 2017.

[42] M. S. B. A. Abd El-Karim, O. A. Mosa El Nawawy, and A. M. Abdel-Alim, "Identification and assessment of risk factors affecting construction projects," HBRC Journal, vol. 13, no. 2, pp. 202-216, 2017.

[43] M. M. Ghazal and A. Hammad, "Application of knowledge discovery in database (KDD) techniques in cost overrun of construction projects," International Journal of Construction Management, vol. 20, pp. 1-15, 2020.

[44] A. B. Senouci and S. A. Mubarak, "Multiobjective optimization model for scheduling of construction projects under extreme weather," Journal of Civil Engineering and Management, vol. 22, no. 3, pp. 373-381, 2016.

[45] S. A. Assaf and S. Al-Hejji, "Causes of delay in large construction projects," International Journal of Project Management, vol. 24, no. 4, pp. 349-357, 2006.

[46] C. Kaliba, M. Muya, and K. Mumba, "Cost escalation and schedule delays in road construction projects in Zambia," International Journal of Project Management, vol. 27, no. 5, pp. 522-531, 2009.
[47] H. A. M. Abusafiya and S. M. A. Suliman, "Causes and effects of cost overrun on construction project in Bahrain: part I (ranking of cost overrun factors and risk mapping)," Modern Applied Science, vol. 11, no. 7, p. 20, 2017.

[48] F. Afzal, S. Yunfei, M. Nazir, and S. M. Bhatti, "A review of artificial intelligence based risk assessment methods for capturing complexity-risk interdependencies," International Journal of Managing Projects in Business, vol. 14, no. 2, pp. 300-328, 2019.

[49] M. Khoshgoftar, A. H. A. Bakar, and O. Osman, "Causes of delays in Iranian construction projects," International Journal of Construction Management, vol. 10, no. 2, pp. 53-69, 2010.

[50] Z. Rachid, B. Toufik, and B. Mohammed, "Causes of schedule delays in construction projects in Algeria," International Journal of Construction Management, vol. 19, no. 5, pp. 371381, 2019.

[51] A. S. Faridi and S. M. El-Sayegh, "Significant factors causing delay in the UAE construction industry," Construction Management \& Economics, vol. 24, no. 11, pp. 1167-1176, 2006.

[52] L. Le-Hoai, Y. D. Lee, and J. Y. Lee, "Delay and cost overruns in Vietnam large construction projects: a comparison with other selected countries," KSCE Journal of Civil Engineering, vol. 12, no. 6, pp. 367-377, 2008.

[53] M. M. Omoush, "Assessing and prioritizing the critical success factors and delays of project management implementation: empirical evidence at construction projects in Jordan," International Journal of Business and Management, vol. 15, no. 10, p. 117, 2020.

[54] G. A. Bekr, "Identifying factors leading to cost overrun in construction projects in Jordan," Journal of Construction Engineering, Technology \& Management, vol. 5, no. 3, pp. 25-33, 2015, [Online]. Available: http://www.stmjournals. com. 